Nig. J. Biotech. Vol. 36(2): 27 - 32 (Dec 2019)

ISSN: 01891731

Available online at

NIGERIAN JOURNAL OF

BIOTECHNOLOGY

http://www.ajol.info/index.php/njb/index

and www.biotechsocietynigeria.org

DOI: https://dx.doi.org/10.4314/njb.v36i2.4

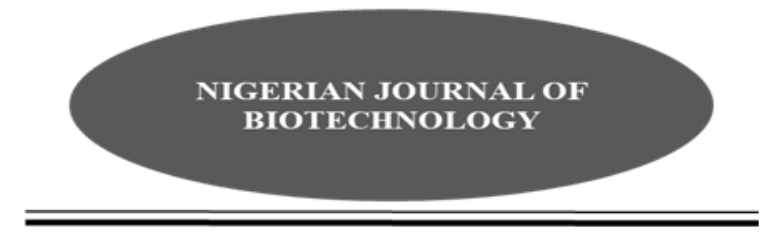

\title{
Molecular characterization of fungi associated with stored soybean (G/ycine max L) seeds
}

\author{
*Ikechi-Nwogu, C. G. and Okene, F. C. \\ Department of Plant and Biotechnology, University of Port Harcourt, Rivers State, Nigeria.
}

\begin{abstract}
Soybean is an important legume that has high quality protein and oil for food and feed. Despite the importance of this legume, the crop is affected by several post-harvest diseases caused by fungi. A study was carried out to identify the fungal species associated with the seeds of soybean using molecular techniques. The DNA of the isolate, was molecularly characterized using Internal Transcribed Spacer 1 (ITS-1) molecular marker. The isolate DNA sequence, was aligned using the Basic Local Alignment Search Tool for nucleotide (BLASTN) 2.8.0 version of the National Center for Biotechnology Information (NCBI) database. The results showed that the isolate sequence was 98\% identical to Diaporthe spp. Voucher VP51, 98\% identical to Diaporthe schini isolate L5N71 and $\mathbf{9 8 \%}$ identical to Diaporthe schini strain B125. These findings showed that Diaporthe spp. is one of the causal fungal pathogens of post-harvest diseases of soybean seeds. It is anticipated that these results will provide information on culturing Diaporthe species also provide the basis for further study to show their antibiotic and anti-cancerous, enzymes and secondary metabolites producing ability.
\end{abstract}

Keywords: Soybean, Diaporthe schini and RBCL marker

Email: *chinyerum.nwogu@yahoo.com; Tel: +2348032325098

\section{Introduction}

Soybean (Glycine $\max \mathrm{L}$ ) is one of the important legumes and has a source of high quality protein, for human and animal consumption (Palacios et. al., 2004). They can produce at least twice as much protein than any other key vegetable or grain crop besides hemp. According to the US Food and Drug Administration, soybean is a good source of protein for vegetarians (Dotzel, 1999). Despite being one of the most important legumes in the world, soybean plants are vulnerable to a wide range of diseases for example, Phomopsis seed decay- Diaporthe longicolla and parasites (Herbert, 2009). To study the pathogens that cause diseases in soybean and to gather up information on how to management the diseases, there is need to identify these pathogens.

There are conventional methods that have been used to identify these pathogens; however, these methods are bulky and inefficient (Hill, 1996). Efficient identification of disease causing fungal pathogens of soybean, is proper because according to St-Germain and Summerbell (2003), diseases caused by fungi have become a noteworthy medical problem and are increasing at a disturbing rate. The increase in the number of patients that are not immuno-competent, have emphasized the significance of precise identification of fungi. To accurately identify these pathogens, molecular characterization technique has been employed to verify the identification of the fungi pathogens (Gontia-Mishra et. al., 2013; Bechem and Afanga, 2017). Therefore, this study was aimed at identifying the fungal pathogens associated with the post-harvest diseases of soybean using macro- and micro-morphological identification, and validating the identification using molecular characterization technique.

\section{Materials and Methods}

\section{Source of plant material}

Seeds were obtained from National Centre for Genetic Resources and Biotechnology (NACRAB) Ibadan, Oyo State. 


\section{Study Area}

The study was conducted in Mycology/ Pathology laboratory of Plant Science and Biotechnology and Regional Centre for Biotechnology and Bio-fuel Research Laboratory were DNA extraction was carried out, University of Port Harcourt. Amplification and sequencing of the PCR products were done at the International Institute for Tropical Agriculture (IITA) Ibadan.

\section{Isolation of Fungi from soybeans using Blotter Method} Standard Blotter Method recommended by International Seed Health Testing Association (ISTA, 2016) was used to isolate fungi pathogens associated with stored maize. Petri dishes were lined with 3 layers of Sterile Whatman's $9 \mathrm{~cm}$ filter papers and moist with sterile distilled water. The stored maize used were sorted to remove diseased ones, then soaked in $70 \%$ ethanol for 2-3 minutes and rinsed twice in sterilized distilled water; after which they were placed in the Petri dishes equidistantly and incubated at $25 \pm 2^{\circ} \mathrm{C}$ for 3-7 days at the Pathology/Mycology laboratory of the Department of Plant Science, University of Port Harcourt, Rivers State, Nigeria. The most common soyabean isolate was coded SB-3A and SB-3B.

Morphological and microscopic characterization and identification

The fungal mycelium of only two (2) unknown fungi was found and cultured on Potato Dextrose Agar medium at room temperature for 7 days. The morphological identification of isolates was conducted by visually observing the mycelium and compared with the pictorial guide by Snowdon (1990). Colonies were compared for their diameters, overall colors, colors of conidia, reverse colors, texture, zonation and sporulation. The isolate was also subjected to microscopic analysis for visual identification using an electron binocular microscope at X40.

Molecular characterization using the Internal Transcribed Spacer (ITS) marker and identification

The Genomic DNA of the 2 isolates SB-3A and SB-3B found on the seeds, was extracted following the protocol of Quick-DNA ${ }^{\mathrm{TM}}$ Fungal/Bacterial MiniPrepKit (Zymo Research Group, California, USA) as described by the manufacturer, with modifications at the Regional Center for Biotechnology and Bioresources (RCBB), University of Port Harcourt, Choba, Rivers State, Nigeria. The SB-3B isolate DNA quantity and concentration were measured using Nano-Drop 2000c spectrophotometer (Thermo fisher Scientific Inc. Wilmington, Delaware, USA). The DNA purity was measured as a ratio of absorbance at $280 \mathrm{~nm}$ to that of $260 \mathrm{~nm}$. The DNA sample of the SB-3B isolate was sent to the International Institute of Tropical Agriculture (IITA) Bioscience Center, Ibadan, Nigeria for amplification and sequencing. The primers used to amplify fragments of the nuclear ribosomal DNA (rDNA) of the SB-3B isolate were the Internal Transcribed Spacer 4 (ITS4) with the sequence TCCTCCGCTTATTGATATGS and ITS5 with the sequence GGAAGTAAAAGTCGTAACAAGG. The amplicons were sequenced using the ABI 3500 capillary electrophoresis sequencer. The DNA sequence file was saved in the Bioedit file with extension .ab1. The sequence was analyzed using the Molecular Evolutionary Genetics Analysis (MEGA) version 7.0.26 software, and aligned using the Basic Local Alignment Search Tool for nucleotide (BLASTN) 2.8.0 version of the National Center for Biotechnology Information (NCBI) database.

\section{Results}

Isolation, morphological and microscopic identification of fungi associated with Soyabean

Two unidentified fungal organisms SB-3A and SB-3B were isolated and found to be associated with Soyabean. On PDA, the isolates developed scanty mycelia and conidiomata had dark brown to black colour. The conidia are rarely branched, tapering towards the apex. Then on the reverse, the isolate was observed to develop greyish to smoke-grey colour. From the microscopic, the isolate was identified as a Diaporthe species.

\begin{abstract}
Molecular characterization using the Internal Transcribed Spacer (ITS) marker and identification The genomic DNA of the isolates SB-3A and SB-3B of Soybean (Glycine max $\mathrm{L}$ ) were successfully extracted and showed good quality. The Nanodrop result (Table 1 and Fig. 1) showed that the concentrations of the DNA of the isolates were $18.4 \mathrm{ng} / \mathrm{ul}$ and $19.9 \mathrm{ng} / \mathrm{ul}$ respectively. While the absorption peak of the $260 \mathrm{~nm} / 280 \mathrm{~nm}$ readings were 1.96 and 2.12 respectively and the $260 \mathrm{~nm} / 230 \mathrm{~nm}$ readings were 0.69 and 0.74 respectively. However, to reduce the cost of sequencing, the isolate SB-3B with the highest DNA concentration was selected.
\end{abstract}

Table 1: Concentration of DNA Extracted from Fungal isolates of Soybean SB-3A and SB-3B using Nanodrop (2000c)Spectrophotometer Sample ID |User name |Date and Time |Nucleic Acid Conc. |Unit |A260 |A280 |260/280|260/230 |Sample Type |Factor| 
Ikechi-Nwogu and Okene./ Nig. J. Biotech. Vol. 36 Num. 2 : 27 - 32 (December 2019)

\begin{tabular}{|c|c|c|c|c|}
\hline 3 RCBBR-UNIPORT 6/26/20183:08:19 PM & $18.4 \mathrm{ng} / \mathrm{\mu l}$ & 0.3680 .188 & 1.96 & 0.69 DNA \\
\hline RCBBR-UNIPORT $\quad 6 / 26 / 20183: 09: 02 \mathrm{PM}$ & $19.9 \mathrm{ng} / \mathrm{\mu l}$ & $0.398 \quad 0.188$ & 2.12 & 0.74 DNA \\
\hline
\end{tabular}

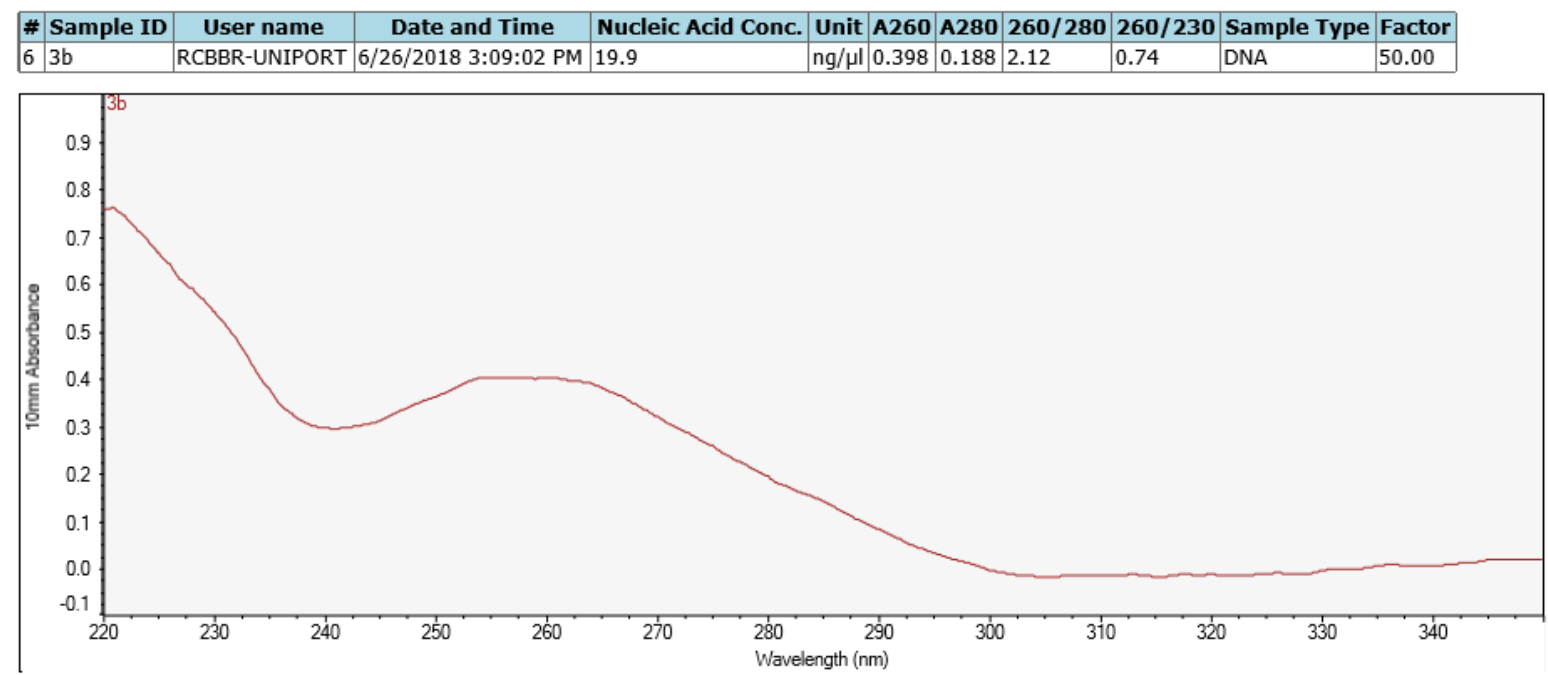

Figure 1: Graph showing Concentration of DNA Extracted from fungal Isolate SB-3B

\section{Polymerase Chain Reaction (PCR) and Gel Electrophoresis}

From the result of the amplified DNA or PCR band of the isolate SB-3B, the amplified DNA showed bands on gel when observed under UV light. From the result, the ladder used indicated that the SB-3B isolate sequence had over 572 base pairs.

DNA Sequencing
The sequencing result after alignment are shown in Figures 2 and 3 . Figure 2 showed the beginning while Figure 3 showed the end of the DNA sequence of the isolate SB-3B. Figure 3 specified that the sequence length was 572 base pairs. This result authenticated the DNA amplification result. Also, from the results, it was noticed that the colours of the bases of the nucleotides were existing in four colours [green: adenine $(A)$, red: thymine $(T)$, blue: cytosine $(C)$, black: guanine $(\mathrm{G})$. These diverse colours allow for easy interpretation of the sequence.



Fig. 2: Beginning of sequence alignment of the DNA of Soyabean after alignment 
Ikechi-Nwogu and Okene./ Nig. J. Biotech. Vol. 36 Num. 2 : 27 - 32 (December 2019)



Fig 3: The End Part of Sequence Alignment of the DNA of Soyabean after Alignment

\section{Sequence Alignment}

The alignment results are presented in figure 4-5. Figure 4 displayed the alignment scores presented as RID N61MDKZ9015 (Expires on 07-22 18:10 pm) Query ID IClIQuery_66419
Description NKECHI_ITS4_38 Description NKECHI_ITS4_38 Molecule type nucleic acid Query Length 572 red lines. The scores of the alignments of all aligned sequences were greater than 200 .
Database Name $\mathrm{nr}$

Description Nucleotide collection (nt) Program Bucleotide collection (nt)
Distribution of the top 100 Blast Hits on 100 subject sequences

Mouse over to see the title, click to show alignments

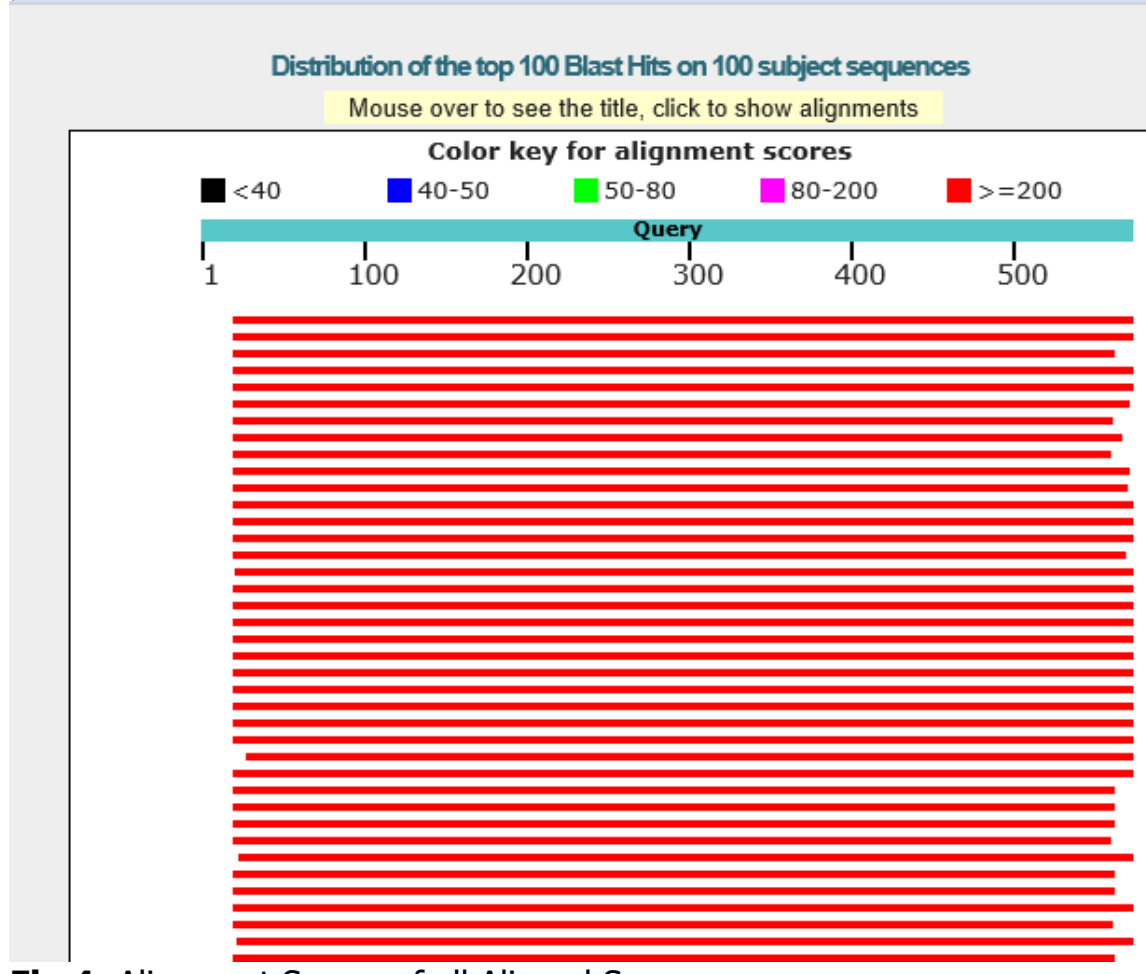

Fig 4: Alignment Scores of all Aligned Sequences 
Ikechi-Nwogu and Okene./ Nig. J. Biotech. Vol. 36 Num. 2 : 27 - 32 (December 2019)

The result of the SB-3B isolate sequence alignments is presented below in Fig. 5. The result indicated that SB-3B isolates sequence aligned with 100 sequences deposited in National Center Biotechnology Information (NCBI) composite biological database. The percentage identity ranged from $97 \%$ to $98 \%$. The results showed that the SB-3B isolate sequence was $98 \%$ identical to Diaporthe spp. Voucher VP51 (red arrow), 98\% identical to Diaporthe schini isolate L5N71 (black arrow) and 98\% identical to Diaporthe schini strain B125 (blue arrow). These findings showed that isolate SB-3B is a Diaporthe spp. Diaporthe spp. is one of the causal pathogens of postharvest diseases of soybean seeds.

\section{Discussion}

Diaporthe belong to the Ascomycota, Pezizomycotina, Sordariomycetes, Diaporthomycetidae, Diaporthales, Diaporthaceae. They have also been recognized as a producer of enzymes and secondary metabolites (Dai et. al., 2005) with antibiotic (Lin et. al., 2005) and have anticancer activity (Kumaran \& Hur, 2009). Furthermore, Diaporthe species in the past, prevent herbivory (Vesterlund et. al., 2011).

The Diaporthe species have often been reported to be plant pathogens, endophytes (they colonize internal plant tissues without causing immediate negative effects) or saprobes fungi, known to cause disease on a wide range of plants hosts that are economically important, causing root and fruit rots, dieback, cankers, leaf spots, blights, decay and wilt (Santos et. al., 2011).

The species of Diaporthe occurring on soybean has been the subject of a considerable amount of research and discussion.

According to Sun et. al. (2003), in a Short Communication, studied two species of Diaporthe (Phomopsis) fungi from soybean plants that were identified by morphological and molecular characterizations they concluded that soybeans are known to harbour a complex of Diaporthe and Phomopsis species. The research by Petrović et al. (2015), identified four Diaporthe taxa found on soybean: Diaporthe phaseolorum var. sojae, the causal agent of pod and stem blight; $D$. phaseolorum var. caulivora and $D$. aspalathi (formerly referred to as $D$. phaseolorum var. meridionalis and they are responsible for serious diseases and significant yield losses.

In this study, Diaporthe spp. was found to be one of the causal fungal pathogens of post-harvest diseases of soybean seeds. From the DNA sequence alignment result (Fig. 3), it was observed that the SB-3B isolate sequence was $98 \%$ identical to Diaporthe spp. Voucher VP51, 98\% identical to Diaporthe schini isolate L5N71 and 98\% identical to Diaporthe schini strain B125.

\section{Conclusion}

This study will provide information on culturing Diaporthe species also provide the basis for further study to show their antibiotic and anti-cancerous, enzymes and secondary metabolites producing ability. It will also increase the knowledge of the fungal species associated with Soybean and enhance disease control, which will increase the production yield.

Diaporthe species not only reduces the quality of seeds for planting by affecting germination potential but also can reduce the quality of seeds which may also reduce flour and oil quality and change the composition of free fatty acids, and affect other quality factors.

\section{References}

Bechem, E. T. and Afanga, Y. A. (2017). Morphological and Molecular Identification of Fungi Associated with Corm Rot and Blight Symptoms on Plantain (Musa paradisiaca) in Macro-Propagators. International J. Biol. and Chem. Sci., 11(6): 27932808.

Dai, J., Krohn, K., Floerke, U., Gehle, D. and Aust, H. J. (2005). Novel Highly Substituted Biaryl ethers, Phomopsines D-G, Isolated from Endophytic Fungus Phomopsis sp. from Adenocarpus foliolosus. European J. Org. Chem., 23: 5100-5105.

Dotzel, M. M. (1999). Food Labeling: Health Claims; Soy Protein and Coronary Heart Disease. Washington, DC: US Food and Drug Administration; Fed. Register, 64:206.

Gontia-Mishra, I., Deshmukh, D., Tripathi N., BardiyaBhurat, K., Tantwai, K. and Tiwari, S. (2013). Isolation, Morphological and Molecular Characterization of Phytate-Hydrolysing Fungi by $18 \mathrm{~S}$ rDNA Sequence Analysis. Braz. J. Mic., 44:1.

Herbert, A., Hull, C. and Day, E. (2009), Corn Earworm Biology and Management in Soybeans. Virginia Cooperative Extension, Virginia State University. pp. 45.

ISTA (International Seed Testing Association) (2016). International Rules for Seed Testing. Rules Amendments. Seed Sci. Tech., 29: 1-127.

Kumaran, R. S. and Hur, B. (2009). Screening of Species of the Endophytic Fungus Phomopsis for the Production of the Anticancer Drug Taxonomy. Biotech. and App. Biochem., 54: 21-30. 
Ikechi-Nwogu and Okene./ Nig. J. Biotech. Vol. 36 Num. 2 : 27 - 32 (December 2019)

Lin, X., Huang, Y., Fang, M., Wang, J., Zheng, Z. and

$\mathrm{Su}$, W. (2005). Cytotoxic and Antimicrobial Metabolites from Marine Lignicolous Fungi, Diaporthe sp. FEMS Micro. Letters, 251: 53-58.

Palacios, M. F., Easter, R. A., Soltwedel, K. T., Parsons, C. M., Douglas, M. W., Hymowitz, T. and Pettigrew, J. E. (2004): Effect of Soybean Variety and Processing on Growth Performance of Young Chicks and Pigs. J. Animal Sci, 82:1108-1114.

Petrović, K., Vidić, M., Riccioni, L., Dorđević, V. and Rajković, D. (2015). Identifying pathogens that cause soybean stem canker. ScienceDaily. Avaliable at: www.sciencedaily.com/releases/2017/11/171103085 953.htm.Retrieved October 31, 2019.

Saghai-Maroof, M. A, Soliman, K. M., Allard J. R. and Allard, R. W. L. (1984). Ribosomal DNA spacerlength polymorphisms in barley: Mendelian inheritance, chromosomal location and population dynamics. Proceedings of National Academy of Sci., 81(24):8014-8084.

Santos, J. M., Vrandečić, K., Ćosić, J., Duvnjak, T. and Phillips, A. J. L. (2011). Resolving the Diaporthe species occurring on Soybean in Croatia. Persoonia, 27: 9-19.

Snowdon, A. L. (1990). A colour Atlas of Post-harvest Diseases and Disorders of Fruits and Vegetables: General Introduction and Fruits. Wolfe Scientific. pp. 1302.

Sun, S., Kim, M. Y. Chaisan, T., Lee, Yin-Won., Van, K. and Lee, Suk-Ha (2013). Phomopsis (Diaporthe) Species as the Cause of Soybean Seed Decay in Korea. J. Phytopatho., 161:2.

St. Germain, G. and Summerbell, R. (2011). Identifying Fungi: A Clinical Laboratory Handbook. Published by Star Publishing Company, P.O. Box 68 Belmont, CA 94002 U.S.A. pp. 1-50.

Vesterlund, S. R., Helander, M., Faeth, S. H., Hyvönen, T. and Saikkonen, K. (2011). Environmental Conditions and Host Plant Origin Override Endophyte Effects on Invertebrate Communities. Fungal Div., 47: 109-118. 